
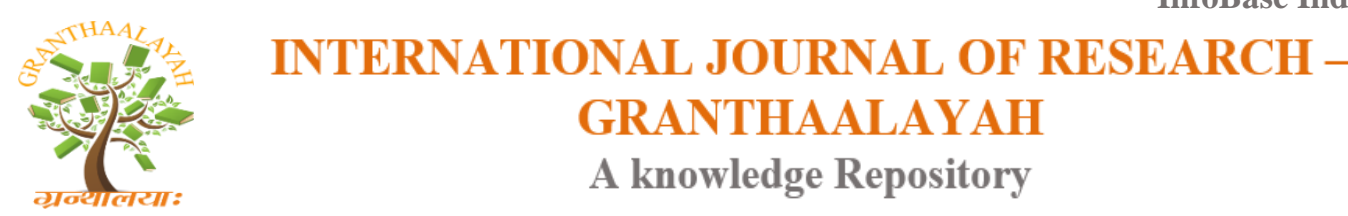

Management

\title{
LIQUIDITY MANAGEMENT AND PROFITABILITY IN ISLAMIC BANKS OF KURDISTAN REGION OF IRAQ: CIHAN BANK FOR ISLAMIC INVESTMENT AND FINANCE AS A CASE STUDY
}

\author{
Abdulla Ibrahim Aziz *1, Atheer Anwar Sharif ${ }^{2}$, Delan Ghafoor Salih ${ }^{3}$ \\ ${ }^{*}$ Sulaimani Polytechnic University, Kurdistan Region, Iraq \\ 2 Anbar University, Iraq \\ ${ }^{3}$ Cihan UniversitylSulimanya, Kurdistan Region, Iraq
}

DOI: https://doi.org/10.29121/granthaalayah.v5.i5.2017.1839

\begin{abstract}
This research intends to analyze the relationship between liquidity management and profitability in one of the most important Islamic banks in Kurdistan Region of Iraq, Cihan Bank for Islamic Investment and Finance P.S.C. It critically examines the bank's liquidity ratios and the liquidity management system to analyze its effectiveness in using its liquid assets in generating positive net income. Also, it uses profitability ratios to analyze the bank's financial position. Then, those results are used to interpret the relationship between the two variables mentioned. The research concludes that better management of liquidity is associated with better profitability. In other words, there is a negative relationship between liquidity and profits in Cihan bank during 2009 to 2015.

Keywords: Liquidity Management; Profitability; Islamic Banks; Pearson Correlation; Liquidity Ratios; Profitability Ratios.

Cite This Article: Abdulla Ibrahim Aziz, Atheer Anwar Sharif, and Delan Ghafoor Salih. (2017). "LIQUIDITY MANAGEMENT AND PROFITABILITY IN ISLAMIC BANKS OF KURDISTAN REGION OF IRAQ: CIHAN BANK FOR ISLAMIC INVESTMENT AND FINANCE AS A CASE STUDY." International Journal of Research - Granthaalayah, 5(5), 73-87. https://doi.org/10.29121/granthaalayah.v5.i5.2017.1839.
\end{abstract}

\section{1) Introduction}

The Islamic banks have started to play important roles in the financial and monetary systems of Muslim states. Partly because of the increasing societal need for such institutions and partly because of the important roles those banks play in their respective economies. Recently, according to The World Bank (2015), there are even Non-Muslim countries such as UK, Luxembourg, South Africa, and Hong Kong who are trying to take advantage of the positive roles Islamic banks play. 
Of the most important indicators of the performance of financial institutions, Islamic banks included, are the financial management tools. The idea behind this research is using such tools in analyzing each of liquidity management and profitability in one of the biggest and most important Islamic banks in Kurdistan Region of Iraq, which is Cihan Bank for Islamic Investment and Finance (referred to as Cihan or Cihan Bank hereinafter). We try to comprehend the bank's liquidity management system and study its ability in maintaining an accepted level of liquidity to assure profitability and solvency of the bank. This is done through studying various liquidity and profitability ratios for the period of 2009-2015 to diagnose the nature of the relationship between the two.

The research has been divided into four parts. Part one is dedicated to explaining the research methodology and aims. It will also present a brief introduction to Kurdistan Region and Cihan bank. The second part focuses on the theoretical perspectives surrounding liquidity, liquidity management and profitability. Next part is dedicated to classifying and analyzing data and information regarding Cihan's liquidity management system and its effect on the actual financial performance of the bank. Finally, in part four, the conclusions are presented followed by recommendations of the research in part five.

\section{2) Research Problem}

Islamic banks have a distinctive structure and operation procedures regarding both liquidity management and profitability among other things. Therefore, this uniqueness should be considered when analyzing the financial performance of those banks, especially how they manage their liquidity. Also, how all this can affect the activities related to the Islamic banks' profitability should be considered. Further, Kurdistan Region has its own special economic and societal characteristics. This makes the Islamic banks' operations in the Region very special; adding another layer to the distinctiveness of the problems this research tries to explore.

Consequently, understanding the liquidity management system of Islamic banks in this Region and understanding the relationship between the effectiveness of the system and profitability is the main idea of this research. Cihan bank is probably where we can fulfill the objectives of the research for the fact that Cihan plays a very important role in the economy of the Region.

Generally, the following are the main problems that the research at hand will cover:

1) How effective is the liquidity management system of Cihan bank as represented by liquidity ratios calculated for financial statements of the bank from 2009 through to 2015 ?

2) What is the level of the bank's profitability as calculated from what is shown in their annual reports for the same period of time?

3) How is the relationship between liquidity management and profitability of the bank for the same period?

4) How can this relationship be used for understanding the performance of Islamic banks and improving the effectiveness of liquidity management systems in a way that leads to better profits? 


\section{3) Research Objectives}

This research tries to achieve the following objectives:

1) Analyzing the effectiveness of Cihan's liquidity management system through financial ratio analysis and examining the components of the system itself.

2) Studying the financial performance of the bank through using a complex of profitability ratios designed for that specific purpose and the bank's net income after taxes.

3) Comprehending the relationship between the bank's way of managing liquidity and its profitability.

\section{4) Importance of the Research}

The importance of this research can be derived from its focus on the Islamic banks that are gradually becoming vital in the contemporary financial and monetary systems. Also, the research focuses on one of the most active and important Islamic banks in Kurdistan Region and Iraq that is Cihan bank, making it even more essential.

Another reason for the importance of this research is integrating both financial ratio analysis and critical examination of Cihan's management approach to liquidity. Both indicators will be used to analyze how successful Cihan has been in managing its liquidity level and translating it into high profitability.

Finally, the research derives some of its importance from being the very first research of this kind, up to our knowledge, with the focus on Islamic banks in Kurdistan of Iraq.

\section{5) Research Methods}

This study employs secondary data obtained from Cihan bank's annual financial statements for the period of 2009 to 2015 as the main source of data. The only primary data used is an interview done with one of the top managers of the bank. Also, this research utilizes both qualitative and quantitative analysis to achieve its stated objectives. Those methods are used because the researchers found them useful and typical for a research of this type.

Profitability data set includes information on return on assets (ROA), return on equity (ROE) and return on deposits (ROD). Further, quick ratio (QR), cash ratio (CR) and current ratio (CUR) ${ }^{1}$ are used to understand liquidity. Pearson correlation is used to answer the research question. This method is designed to test the strength of the relationship between two continuous variables such as the relationship between profitability and liquidity that this research is investigating.

\section{6) Research Question}

Is there a relationship between liquidity management and profitability in Islamic banks such as Cihan?

\footnotetext{
${ }^{1}$ This study calculates QR by deducting Murabaha and Musharaka from current assets considering them the least liquid of the current assets based on their nature.
} 


\section{7) Research Hypothesis}

Null hypothesis: There is no significant relationship between effective liquidity management system at Cihan bank and profitability of the bank's operations.

Alternative hypothesis: There is a significant relationship between liquidity management system at Cihan bank and the profitability of the bank's operations

\section{8) Research Scope and Limitations}

1) Scientific scope: Profitability analysis, liquidity and liquidity management analysis and the relationship between the two.

2) Phase scope: The time period from 2009 to 2015.

3) Geographical scope: Cihan bank for Islamic investment and finance in Kurdistan Region of Iraq.

\section{9) Key Definitions}

The following are some of the key terms of the research with their definitions as apply in the scope of this research:

- Bank liquidity: Liquidity is defined as the bank's ability to meet its short-term obligations.

- Liquidity management in Islamic banks: The process of keeping a balance between the necessity and riskiness of keeping cash and readily convertible to cash assets within the limitation of Islamic sharia law.

- Bank profitability: The ability of the bank to create more wealth than it spends.

\section{Case Presentation}

This research focuses on the case of Cihan bank in the Kurdistan Region of Iraq. Brief descriptions of both the region and the bank are presented in the following.

\section{Kurdistan Region of Iraq}

Kurdistan is a semi-autonomous region northern Iraq that shares borders with Syria, Iran and Turkey. The region depends on the financial rules and regulations of Central Bank of Iraq and relevant Iraqi government bodies through having branches of those institutions in the Region (Central Bank of Iraq, 2004). It has been well-known for its economic boom, making it a safe haven for foreign and local companies investing in post 2003 Iraq. There are branches of many well-known international companies and dozens of different Islamic and conventional banks in the Region (Kurdistan Investment Board, 2015). Albeit, the recent financial developments and political conflicts with Iraq have slowed down the Region's boom in many ways. Regardless, one of the big local companies that has been playing an essential role in Kurdistan is Cihan Group of Companies. 
Cihan bank for Islamic Investment and Finance P.S.C.

Cihan Bank for Islamic Investment and Finance is a member of Cihan Group of Companies. Cihan Group has business lines in various fields such as trading cars, construction, importing tea, education, media, banking, insurance and general trading.

Cihan bank was founded in 2008 as a part of Cihan Group in its headquarters in Erbil, the capital city of Kurdistan Region. By 2009 it began its operations with a capital of 50 billion Iraqi Dinars (IQD) (Cihan Bank, 2009). Cihan continued running profitably thereafter and by the end of 2013 the capital of the bank was three folded to 150 billion IQD's (Cihan Bank, 2013). This is more than 127 million USD in today's exchange rates. The bank has big expansion ambitions. It plans to open a branch in every major city of Iraq by 2022 (Cihan Bank, 2012). As of 2015, the bank has nine branches in the main cities of the Region and Baghdad, Basra, Najaf, Mosul and Kirkuk. Cihan bank is an Islamic bank that alleges to abide by all sharia rules and regulations in its operational, financial and investment activities (cihanbank.com, 2011a). The bank has a specialized Sharia Committee that oversees the bank's activities to make sure they do so. The bank's vision is to be a leading financial institution that provides fully-fledged banking services compliant with sharia to contribute in the development of the society (Cihanbank.com, 2011b).

\section{Theoretical Perspective}

This part tries to present a theoretical framework for the rest of the paper. It starts with explaining the ideas of liquidity and liquidity management focusing on Islamic banks. Then, it will explain the idea of profitability. Finally, it tries to present measures utilized by previous researchers in the field to understand the relationship between the two variables.

\section{Liquidity and Liquidity Management in Islamic Banks}

Liquidity of an asset is its ease of convertibility into cash or a cash equivalent asset (Ali, 2004) without losing much of its value (Basel Committee on Banking Supervision, 2008; BenArab \& Elmelki, 2008). More specifically, liquidity of a bank is defined as the bank's ability to meet its short term obligations (Casu, Girardone, \& Molyneux, 2006). So, a bank with enough liquid assets that can cover its short-term obligations is said to be liquid.

Liquidity is as important for Islamic banks as is for conventional banks (Rasul, 2013). In fact, managing the liquidity level is one of the most important duties a bank, including Islamic ones, should do (Basel Committee on Banking Supervision, 2000). Islamic banks face even more liquidity risks than their conventional counterparts (Ali, 2004), because sources of liquidity in the former are more abundant than the conventional banks (Mohamad, Mohamad, \& Samsudin, 2013). This is inherited from the very structure of the Islamic banking system and relevant religious rules and regulations. First of all, illiquidity of assets is very high in Islamic banks, because, for example, sharia gives bank customers the right to cancel a murabaha contract before the transferring of ownership completed, even if the bank has purchased the commodity (BenArab \& Elmelki, 2008). This can lead to bank's inability to sell those assets at a reasonable price. Second, Islamic banks do not have freedom in dealing with surplus in short-term assets, especially cash. The obvious reason is that Islamic laws forbid receiving interest just like they 
forbid paying it (Casu et al., 2006; Kettell, 2011; Mohamad et al., 2013). Further, the sharia restriction on sale of debt (Ali, 2004) adds another source of illiquidity relevant to Islamic banks and financial institutions only.

In the scope of our study, we define liquidity management in Islamic banks as the process of keeping the balance between the necessity and riskiness of liquidity, since both lack of and too much of liquid assets can have unwanted consequences for the bank. As BenArab and Elmelki (2008) put it; liquidity risk arises when the bank is not able to obtain enough necessary short term assets at a reasonable price leading to difficulties in bank operations. This can and has led to closing down of some Islamic banks (Ali, 2004). Likewise, excessive liquidity can have unwanted consequences for Islamic banks. The reason is that liquid assets generally generate lower returns (Al-Amri, 2009; Casu et al., 2006), for holding liquid assets imposes an opportunity cost on the Islamic bank. Thus, risk of excess liquidity can reduce the profit of banks by the means of the opportunity cost of investing the excess liquid assets. Shortage can be even riskier. This necessitates the call for an effective liquidity management system that can keep liquidity neither too low nor too high while abiding by the rules and regulations of Islamic banking and finance.

To examine the effectiveness of a liquidity management system, researchers use observation and ratio analysis (Al-Amri, 2009). This research uses both methods in its analysis for Cihan bank. The liquidity ratios that are believed to well represent the liquidity status of a bank and have been used by other researcher in similar works such as Shahchera (2012) and Rasul (2013) are current ratio, quick ratio and cash ratio. Therefore, those ratios are utilized in the current research. High enough liquidity ratios indicate that the bank is liquid enough to cover its short term obligations and expenses and is less likely to fall into liquidity difficulties. As mentioned above, having too high or too low ratio results indicates a problem in the liquidity management system of the bank being studied. The following are brief descriptions of the liquidity ratios used in this study:

1) Current ratio

Sometimes referred to as working capital ratio, this is a balance sheet ratio that looks at the short term assets and liabilities of the bank to find out whether the former is big enough to cover the later (readyratios.com, 2015).

Current ratio $=$ current assets/ current liabilities

2) Quick ratio

Inventories of an Islamic bank, such as murabaha contracts, are the most illiquid current assets (Kettell, 2011). Quick ratio excludes inventory from the current ratio for that very reason (Ali, 2004).

Quick ratio $=($ current assets- inventory $) /$ current liabilities

3) Cash ratio

Cash is the most liquid asset of all. Naturally banks need effective cash management strategies as a part of their overall liquidity management system. Cash ratio examines such a system 
calculating the percentage of current liabilities that can be covered by cash and cash equivalents (Al-Amri, 2009).

Cash ratio $=$ cash and cash equivalents/ current liabilities

\section{0) Profitability of Islamic Banks}

Like any other business, one of the major goals of Islamic banks is maximizing the wealth of its shareholders, i.e. to be profitable (Kettell, 2011). A bank is considered profitable when it creates more wealth than it spends and the very sustainability of the bank depends on the ability to do so (Ali, 2004). Like all other aspects of Islamic bank operations, profit creation must abide by the religious injunctions of Islam. Those injunctions include, but are not limited to, profit and loss sharing and prohibition of funding for projects that are considered haram beside prohibition of usury and interest (Kettell, 2011).

To remain profitable under the strict Islamic rules, Islamic banks utilize special ways of doing business. One such method is murabaha, which is a contract for purchase and resale that allows the customer to make purchases without having to take out a loan and/or pay interest. The Islamic bank purchases commodity, then transfers the ownership adding a previously agreed upon profit margin (Hassan \& Bashir, 2014). The customer then pays the price of the goods over installments, effectively obtaining credit without paying interest. Another method Islamic banks use is musharaka. Musharaka literally means partnership; it is a type of profit and loss sharing agreement that involves the Islamic bank providing a portion of capital and other necessary resources to carry out a partnership with another person or company with the condition that the risks and rewards of the project will be borne by both parties (Casu et al., 2006; Kettell, 2011). The common point between musharaka and murabaha and other Islamic ways of finance such as ijara and mudaraba are paying no interest and bearing risks and returns from investment by all parties involved (Bashir, 2003; Hassan \& Bashir, 2014; Kettell, 2011).

The most widely used method to examine the profitability of a firm is ratio analysis (Al-Amri, 2009). The profitability ratios that are believed to well represent a bank's financial status and that have been used by authors of the field such as Rasul (2013) and Bashir (2003) are return on assets (ROA), return on equity (ROE) and return on deposits (ROD). High result in any of those ratios indicates higher profitability of the bank. Those abovementioned ratios are utilized in the current research and each ratio is briefly explained hereinater.

1) Return on assets (ROA)

ROA indicates how much net income is generated per each IQD of bank assets. Higher ROA indicates higher returns made by the Islamic bank on each unit of assets (Casu et al., 2006).

Return on assets $=$ Net income after taxes $/$ Total Assets.

2) Return on equity (ROE)

ROE shows how much net wealth each IQD invested by the shareholders generated. Higher ROE means more wealth was created per each unit invested (Al-Amri, 2009). 
Return on equity $=$ Net income after taxes $/$ Total equity

3) Return on deposits (ROD)

ROD shows how much net wealth was created for each IQD deposited by the bank's customers. Higher ROD indicates more wealth for each IQD deposited (Al-Amri, 2009; Readyratios.com, 2015).

Return on Deposits $=$ Net Income/ Total Deposits.

\section{The Relationship between Liquidity Management and Profitability in Islamic Banks}

There is a general agreement among the authorities of the field that quality management of liquidity is highly correlated with profitability. For example, in various studies on the impact of liquidity on profitability (Ali, 2004; Bordeleau \& Graham, 2010; Rasul, 2013; Shahchera, 2012), the authors have concluded that high liquidity has a positive impact on profitably. However, they say, there comes a point at which higher liquidity leads to demolishing the banks' profits. The authors however agree that this relationship is not linear and there is no liquidity level that could lead to higher profits regardless of other factors. We can presume that this relationship is logical for most of the Islamic banks, including Cihan. Researchers also agree that stability in liquidity can have positive impact on wealth creation (Hassan \& Bashir, 2014; International Financing Review, 2007).

Merely measuring the ratios described above is of no use for assessing the liquidity and profitability performance of an Islamic bank. To make sense, those ratios need to be further studied and compared with themselves over time and with one another over a period of time looking for changes and trends in one ratio compared to other ratios. Measuring the relationship is done through first measuring both liquidity and profitability of the bank as explained above. In our and similar research (Rasul, 2013; Shahchera, 2012; Zygmunt, 2013) the two results are then compared and the relationship is explored based on the correlation between the variables.

\section{Preliminary Analysis}

In what follows, the preliminary analysis, descriptive statistics such means, maximums, minimums and standard diversions are presented. Also, line graphs are presented to compare different ratios. The analysis is done using SPSS version 22. Table 1 shows the descriptive results.

Table 1: Descriptive statistics

\begin{tabular}{|l|l|l|l|l|l|}
\hline Variables & Mean & Maximum & Minimum & Std. & Observations \\
\hline ROA & 0.05 & 0.08 & 0.02 & 0.03 & 7 \\
ROE & 0.13 & 0.21 & 0.04 & 0.06 & 7 \\
ROD & 0.21 & 0.35 & 0.03 & 0.13 & 7 \\
QR & 0.76 & 1.11 & 0.56 & 0.66 & 7 \\
CR & 0.55 & 0.94 & 0.42 & 0.19 & 7 \\
CUR & 0.97 & 0.46 & 0.07 & 0.45 & 7 \\
\hline
\end{tabular}


Figure 1 below illustrates the three liquidity ratios. The graph shows that all the three liquidity ratios used in our research co-vary and are close to their industry averages. The exception is the first years of the bank's operations, 2009 and 2010. These two years witness high liquidity. That can be considered normal for any bank at the beginning of its operations. After the first couple of years, the ratios begin to get closer and closer to what could be considered normal, especially in the years of 2012 and 2013. Then, the bank seems to be very successful in maintaining this reasonable liquidity over the period of this research.

Focusing on current ratio, same graph, we notice that it is very high in year 2009 at around 1.6. This is being generally accepted as normal showing that the bank has more current assets than current liabilities by around $60 \%$. This might mean that the Islamic bank in question has a lot of current assets that are unassigned. Therefore, as mentioned above, this will impose an opportunity cost on the bank that is equal to the wealth those current assets could have generated if had been invested properly. The bank seems to realize that very well. As starting from 2011, the current ratio gets reasonably low at less than 1. It is also capable of maintaining this rate till 2015.

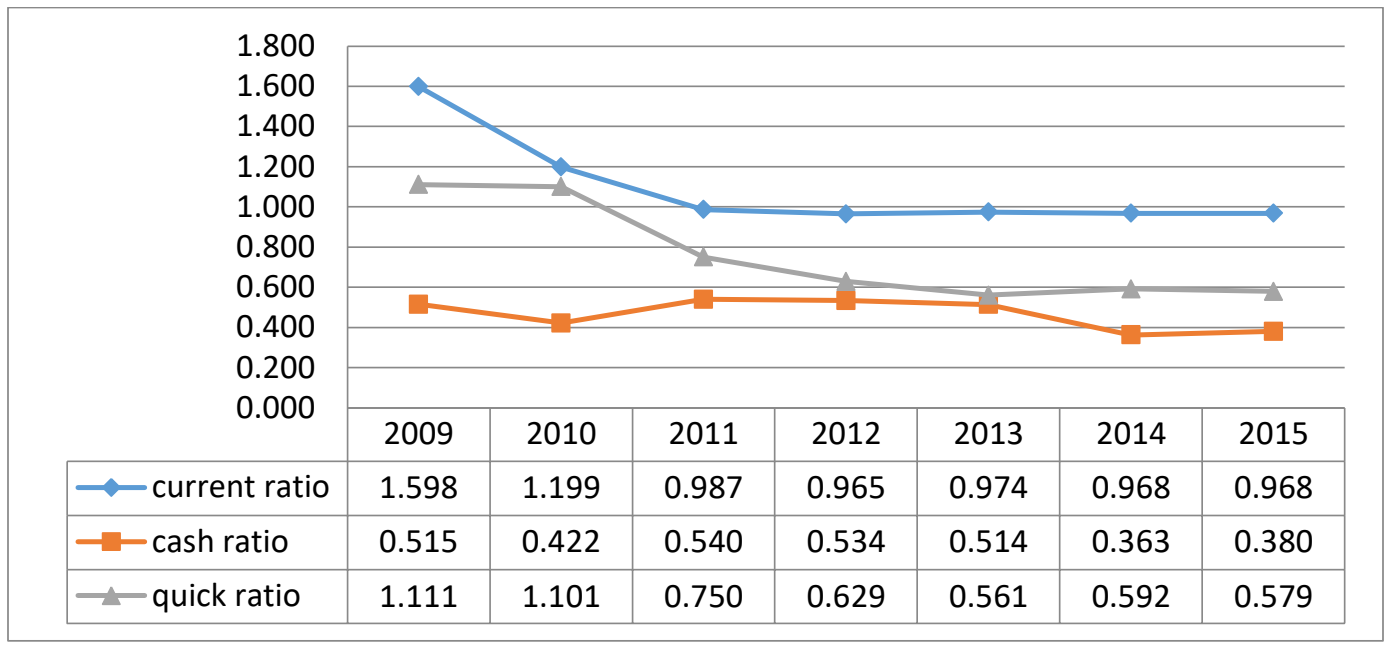

Figure 1: Liquidity ratios for Cihan bank from 2009 to 2015

The stability evident in the cash ratio, as shown in Figure 1 refers to effective management of cash, the most liquid asset of the bank. Throughout the studied era, cash ratio fluctuates around 0.5 showing that the cash can cover around 36 to 54 per cent of current liabilities.

Finally, there is a noticeable change in the level of quick ratio over the years. In 2009 and 2010, the ratio is very high. Then, it starts to decline and stabilize until it gets to 0.561 by the end of 2013 and stays stable till 2015. This shows that the management has been effective once again in managing their liquidity. The inventory of Islamic banks includes murabaha and musharaka contracts and decrease in the quick ratio means increase in those contracts. In other words, lower quick ratio shows that the bank has been successful in investing more current assets through attracting more customers. The bank's financial statements show that the rate of murabaha and musharaka contracts in 2011 are four times bigger than 2009. 
Figure 2 bellow shows all profitability ratios; ROA, ROE and ROD together, to show the correlation among them. It is apparent from the graph that there is some correspondence between the three. Also, all three show that each of assets, equity and deposits have yielded profits. We can also notice a gradual increase in profitability year after year. This steady increase in the profitability indicators of the bank signals betterment in the bank's overall performance, especially its financial performance. However, there is a slight decrease in return on assets for 2013. This could be due to the fact that in that specific year the bank has invested lots of money in long term assets as shown in their 2013 annual statement. Moreover, both returns on deposits and on equity have declined in 2014.And all these are corrected in the following year.

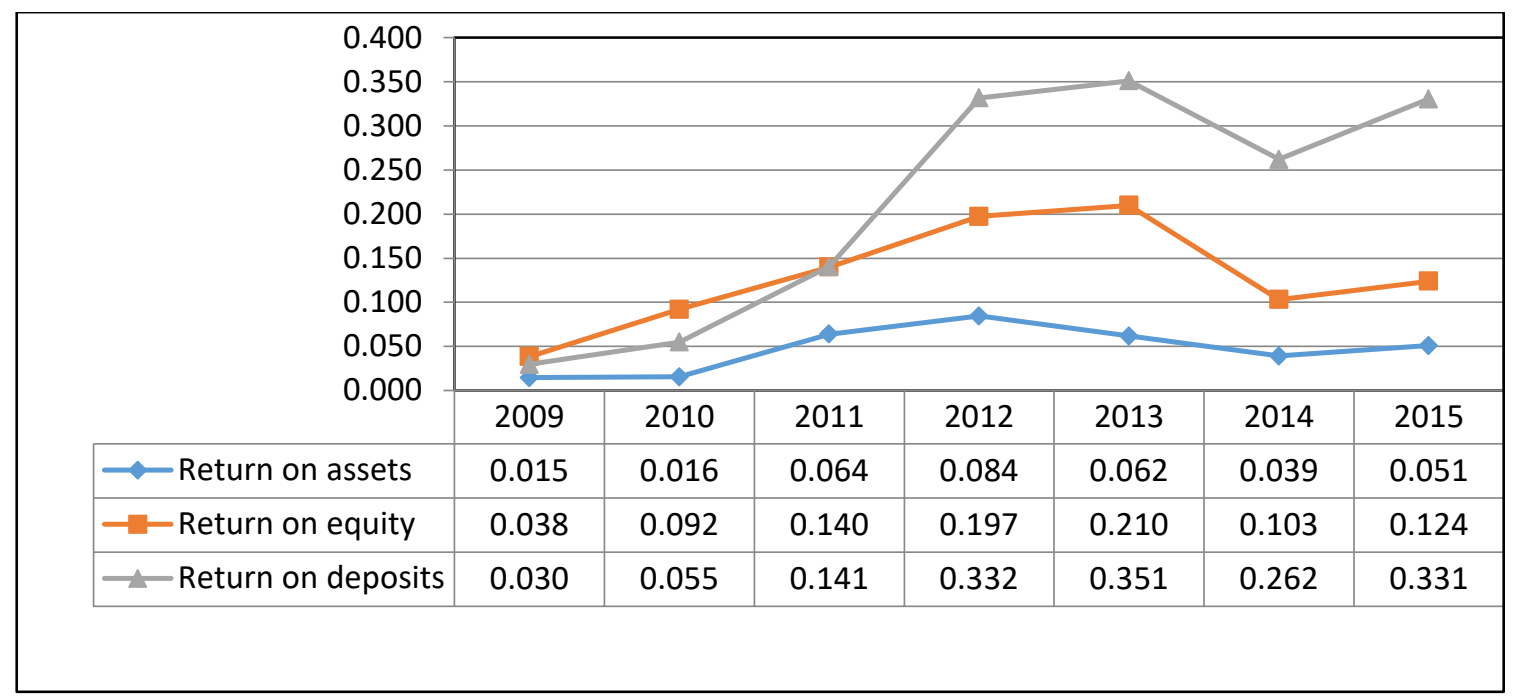

Figure 2: Liquidity ratios in Cihan bank from 2009 to 2015

It is also clear from the figure above that the proportion of profits coming from return on deposits was significantly higher than return on equity and return on assets. While, the figure for return on assets is the lowest. Generally, the bank has been profitable since the beginning of the period of our study. By 2015, its profitability has increased by $700 \%$.

\section{Description and Analysis of the Relationship between Liquidity Management and Profitability in Cihan Bank}

This part of the research will study the nature of the relationship between liquidity of Cihan bank from 2009 to 2015 and its profitability in the same period. This is done through presenting the relation between each liquidity ratio and each and net profit after taxes. 


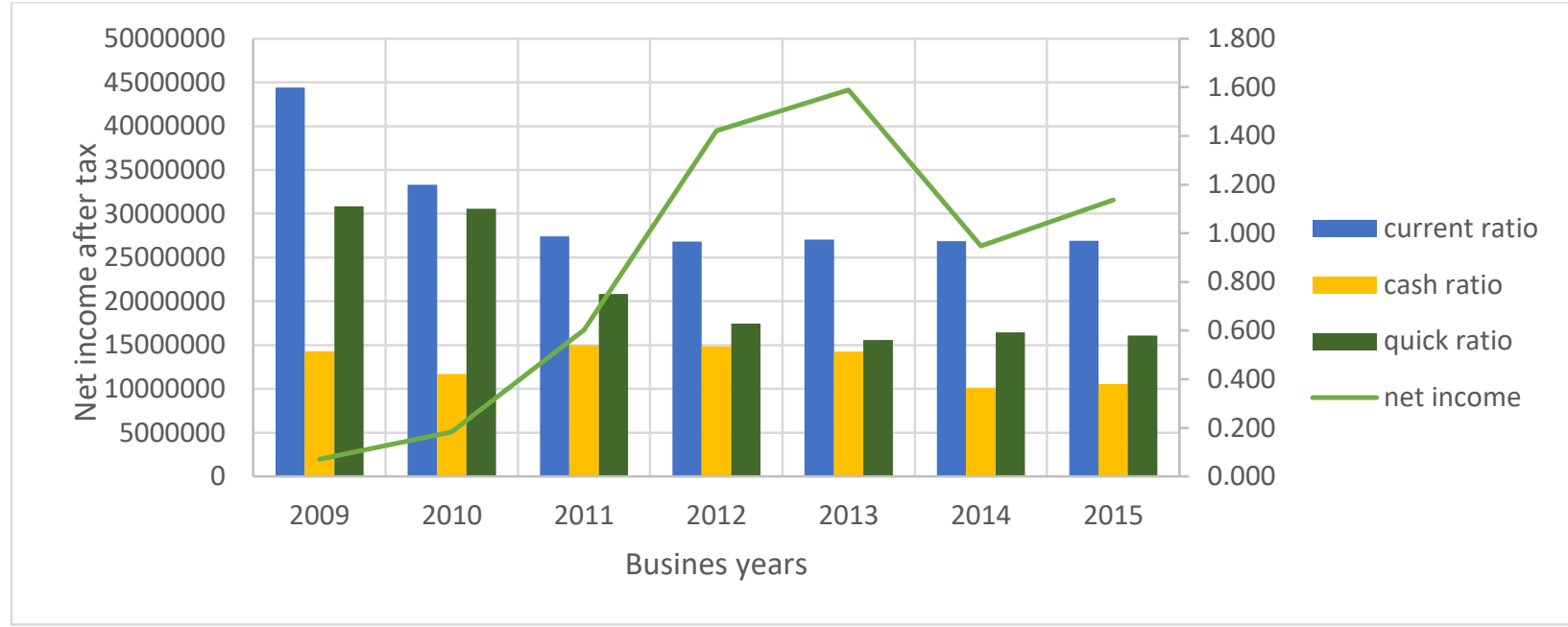

Figure 3: Relationship between the net profit and every liquidity ratio

As soon as the current ratio starts to stably decrease, profit starts to increase steadily, see the graph above. This negative relationship between current ratio and profit is especially apparent in the years 2011, 2012 and 2013, the years of Cihan's stability and functionality. Although profitability decreases a little bit the next year, but soon starts to incline again. This shows that Cihan starts off with too many current assets compared to current liabilities, but then it starts to invest some of its liquid assets leading to a decrease in the liquidity ratios and better profits. This verifies that better management of the Islamic bank's liquidity will reflect in the bank's financial performance and Cihan bank is a good example for that.

Further, as shown on the Figure 3 above, cash ratio keeps relatively stable at around 0.5 all the time. Meanwhile, all profitability indicators start and keep raising showing that higher profitability at Cihan bank partly depends on stabilizing the amount of cash to current liabilities. The graph also shows that Cihan has been quite successful in doing so.

Taking a close look at the same figure indicates that as soon as quick ratio starts to decline, profitability starts to increase; showing that there is a negative correlation between quick ratio and net income after tax, especially for the years 2011-2013. This proves that better management of liquidity has a noticeable positive influence on the profitability of Cihan. It also shows that Cihan owns an effective liquidity management system.

Analyzing both liquidity and profitability ratios shows that there is a co-relation between liquidity management and profitability of Cihan bank. The co-relations can generally be described as negative; better management of liquidity represented by more stable decrease liquidity indicators to a certain threshold, leads to more profitable bank operations. This proves the viewpoints discussed beforehand. It also proves that Cihan has a well developed and managed liquidity system as explained in next section.

\section{Further Analysis}

Further analysis includes testing correlation of profitability and liquidity indicators, and their interpretation used to answer the research objective. A summary of the correlation matrix is 
presented in Table 2. 5\% significant level was supposed during the hypotheses testing. The correlation coefficient between $\mathrm{QR}$ and all profitability ratios ROA, ROE and ROD have negative values of (-0.779), (-0.734) and (-0.946) respectively. Also, the correlation coefficient between ROE and ROD have a significant negative relationship with CUR with values of ($0.254)$ and $(-0.521)$ respectively. It seems that the association is negative. Therefore, we reject the null hypotheses and conclude that there is a significant negative relationship between profitability indicators and liquidity management. This means that lower liquidity can lead to higher profits.

Further, this study found an insignificant relationship between CR and all profitability indicators. Furthermore, the correlation analysis shows that there is a significant and strong positive relationship among the profitability ratios and an insignificant relationship among the liquidity management indicators.

Table 2: Correlation matrix

\begin{tabular}{|l|l|l|l|l|l|l|}
\hline Variables & ROA & ROE & ROD & QR & CR & CUR \\
\hline ROA & 1 & $0.883^{*}$ & $0.761^{*}$ & $-0.779 *$ & 0.231 & -0.281 \\
ROE & $0.883^{*}$ & 1 & $0.790^{*}$ & $-0.734^{*}$ & -0.093 & $-0.254^{*}$ \\
ROD & $0.761^{*}$ & $0.790^{*}$ & 1 & $-0.946^{*}$ & 0.508 & $-0.521^{*}$ \\
QR & $-0.779 *$ & $-0.734^{*}$ & $-0.946^{*}$ & 1 & -0.317 & 0.670 \\
CR & 0.231 & -0.093 & 0.377 & -0.317 & 1 & 0.217 \\
CUR & -0.281 & $-0.254^{*}$ & $-0.521^{*}$ & 0.670 & 0.217 & 1 \\
\hline
\end{tabular}

*Correlation is significant at the 0.05

\section{Liquidity Management System at Cihan Bank}

The ratio analysis above concluded that the bank has been successful in managing its liquidity in a way that has led to a steady increase in its profitability. Observing the management system in Cihan at first hand, the researchers confirm the results with some room for improvement.

According to our analysis for the operations of the bank, we discovered that liquidity is directly supervised by Cihan's board of trustees that includes executive and non-executive board members. Also, all the branches of the bank are required to submit daily reports back to Cihan's board in its headquarters in Erbil (Mohammed, 2015). This is exactly what the Basel Committee on Banking Supervision (2000) calls for when it advises that the board's direct involvement in day to day management of liquidity and a two way communication between the board and relevant line managers are crucial. However, Cihan lacks on the communications side as the communication is still one way and lower level managers are not involved in the decisions regarding liquidity.

Another requirement for an effective management of liquidity is having a strong internal control over daily operations (Basel Committee on Banking Supervision, 2000) as well as a strong external control (BenArab \& Elmelki, 2008). Cihan has a body of internal inspectors that conducts unannounced visits to all branches at least twice a month and does a systematic analysis of the branch's financial position and reports its findings back to the board (Mohammed, 2015). 
Also, the external control is represented by the inspectors from the Central Bank of Iraq (Central Bank of Iraq, 2004) and an external auditing company called Tutinchi (Mohammed, 2015).

Further, Islamic banks need to have contingency plans in place in case they face liquidity problems (Ali, 2004; Basel Committee on Banking Supervision, 2008; Shahchera, 2012). At Cihan, when asked how they deal with liquidity crises, Mohammed (2015), the manager of one of bank's branches mentioned that if the shortcoming or excess liquidity are at one of our branches, other branches will help. If the crisis is bank wide, we have no other option but to depend on the central bank of Iraq. Inter-branch dependency has proven successful for Cihan, yet the wide belief is that without an efficient capital market to operate within, Islamic banks will not continue to grow meaningfully (International Financing Review, 2007). Right from their first year and in their 2009 annual report, Cihan claims to have established good relations with international banks in the neighboring and other Arab countries. By the end of 2013 the list of partner banks gets much longer and includes more international banks and financial bodies. Yet, the effects of such relations on liquidity are not well documented for Cihan.

\section{Conclusions}

The study aimed at investigating the relationship between liquidity management and profitability in Cihan Islamic Bank for Islamic Investment and Finance in Kurdistan Region of Iraq from 2009 to 2015. Pearson correlation was used in analyzing this relationship. The results showed a statistically significant negative relationship between profitability and liquidity. These results align with previous researches that concluded higher liquidity management lead to more profits. In short, this research reached the following conclusions:

1) The researchers accept the research's alternative hypothesis that there is a negative relationship between effective management of liquidity at Cihan bank and the bank's improved financial performance.

2) Profitability ratios were very responsive to changes in current and quick ratios.

3) Cihan's cash ratio remains relatively stable throughout the study period and this is correlated with higher profitability.

4) The strongest relationship is between each of ROE and ROD and profitability.

5) The first years of Cihan as a bank, 2009 and 2010, see a level of fluctuation in both liquidity and profitability signs.

6) Until 2011 increases in profitability are stable and slow. After that period, the increase is sharper. This increase is especially apparent in both ROE and ROD.

7) Although there is a sudden decrease in Cihan's profits in 2014, the bank goes back on track the very next year.

8) The bank is profitable from 2009 to 2015.

9) The bank seems to be too liquid at the beginning of the study period, but after two years it successfully stabilizes their liquidity.

10) The researchers concluded an effective management system in the bank when it comes to liquidity. 


\section{Recommendation}

1) The key to sustainable profit generation at Cihan, and other Islamic banks, is maintaining the good liquidity management system and improving it.

2) Cihan bank needs to identify the factors that affect liquidity and liquidity management and try to use those factors in a way that leads to stabilizing and improving liquidity of the bank.

3) Bettering the overall banking activity and improving performance are needed to create more wealth.

4) It is very essential that there is a two way communication between the board and the managers that are directly responsible for managing liquidity at Cihan. The managers should also have decision making authority in that regard.

5) The bank needs to have better and more contingency plans in place in case of liquidity problems. One such plan is a productive interdependence with other Islamic banks in the region.

6) Islamic banks, including Cihan, need the contribution of its national and international counterparts in the liquidity solutions.

7) Suggestions for future research:

a) Studying the relationship between liquidity ratios and other performance indicators such as financial leverage ratios, activity ratios and market ratios.

b) Focus on comparative studies among and between various Islamic banks in the region.

c) Studying and analyzing the relationship between liquidity and profitability for longer periods of time and using statistics to better understand the relationship.

\section{Acknowledgements}

This research was funded by Cihan University, Sulimanya, Kurdistan Region - Iraq.. The authors thank the Cihan bank for providing the data.

\section{References}

[1] Al-Amri, M. (2009). Financial Management. Jordan: Dar Al-Manahij.

[2] Ali, S. S. (2004). Islamic Modes of Finance and Associated Liquidity Risks Paper presented at the Conference on Monetary Sector in Iran: Structure, Performance and Challenging Issues TehranIran. http://www.sbp.org.pk/departments/ibd/lecture_6_islamic_modes_finance_liquidity.pdf

[3] Basel Committee on Banking Supervision. (2000). Sound Practices for Managing Liquidity in Banking Organisations. Basel.

[4] Basel Committee on Banking Supervision. (2008). Principles for Sound Liquidity Risk Management and Supervision. Basel.

[5] Bashir, A.-H. M. (2003). Determinants of profitability in Islamic banks: some evidence from the Middle East. Islamic Economic Studies, 11(1), 31-57.

[6] BenArab, M., \& Elmelki, A. (2008). Managing Risks and Liquidity in an interest free banking Framework: The case of the Islamic banks. International Journal of Business and Management, 3(9), 81-95.

[7] Bordeleau, É., \& Graham, C. (2010). The Impact of Liquidity on Bank Profitability working paper (38) (pp. 3-22): Bank of Canada. 
[8] Casu, B., Girardone, C., \& Molyneux, P. (2006). Introduction to Banking: Prentice Hall Financial Times.

[9] Central Bank of Iraq. (2004). Iraqi Banking Law. In C. B. o. Iraq (Ed.), 94. Baghdad.

[10] Cihan Bank. (2009). Cihan bank for Islamic investment and finance annual report 2009.

[11] Cihan Bank. (2010). Cihan bank for Islamic investment and finance annual report 2010.

[12] Cihan Bank. (2011). Cihan bank for Islamic investment and finance annual report 2011.

[13] Cihan Bank. (2012). Cihan bank for Islamic investment and finance annual report 2012.

[14] Cihan Bank. (2013). Cihan bank for Islamic investment and finance annual report 2013.

[15] Cihan Bank. (2014). Cihan bank for Islamic investment and finance annual report 2014.

[16] Cihan Bank. (2015). Cihan bank for Islamic investment and finance annual report 2015.

[17] cihanbank.com. (2011a). Company profile. Retrieved 18/5/2015, from http://www.cihanbank.com/lang/en/Company_Profile.aspx

[18] Cihanbank.com. (2011b). Vision and Mission. Retrieved 20/6/2015, from http://www.cihanbank.com/lang/en/Vision_and_mission.aspx

[19] Hassan, M. K., \& Bashir, A.-H. M. (2014). Determinants of Islamic banking profitability. Retrieved 19/06/2015, from Researchgate.org http://www.researchgate.net/publication/228846468_Determinants_of_Islamic_banking_profitabil ity

[20] International Financing Review. (2007). Issues in Islamic liquidity. http://www.ifre.com/issues-inislamic-liquidity/552713.fullarticle

[21] Islamic Finance. (2015). The World Bank. Retrieved 15 February 2017, from http://www.worldbank.org/en/topic/financialsector/brief/islamic-finance

[22] Kettell, B. (2011). Introduction to Islamic Banking and Finance. UK: West Sussex: Wiley.

[23] Kurdistan Investment Board. (2015). Investment factsheet. Kurdistan: Retrieved from http://www.kurdistaninvestment.org/docs/Investment\%20Factsheet\%20Kurdish.pdf.

[24] Mohamad, A. A. S., Mohamad, M. T., \& Samsudin, M. L. (2013). How Islamic Banks of Malaysia Managing Liquidity? An Emphasis on Confronting Economic Cycles. International Journal of Business and Social Science, 4(7), 253-263.

[25] Mohammed, A. (2015, 23/06/2015). [Personal communication with Azad Mohammed, Cihan bank's branch manager].

[26] Rasul, L. (2013). Impact of Liquidity on Islamic Banks' Profitability: Evidence from Bangladesh. Acta Universitatis Danubius, 9(2), 23-36.

[27] Readyratios.com. (2015). Liquidity Ratios. Retrieved 10/5, 2015, from http://www.readyratios.com/reference/liquidity/?sphrase_id=33396

[28] Shahchera, M. (2012). The Impact of Liquidity on Iranian Bank Profitability. Money and Economy, 7(1), 139-160.

[29] Zygmunt, J. (2013). Does liquidity impact on profitability? Paper presented at the Conference of Informatics and Management Sciences, Slovakia.

*Corresponding author.

E-mail address: delangh@yahoo.co.uk 